\title{
КОНЦЕПТУАЛЬНАЯ СЕДИМЕНТОЛОГИЧЕСКАЯ МОДЕЛЬ БОТУОБИНСКОГО ПРОДУКТИВНОГО ГОРИЗОНТА СРЕДНЕБОТУОБИНСКОГО НЕФТЕГАЗОКОНДЕНСАТНОГО МЕСТОРОЖДЕНИЯ
}

\author{
А. В. Плюснин \\ ООО «Тюменский нефтяной научный центр», г. Тюмень
}

Поступила в редакцию 2 февраля 2019 г.

\begin{abstract}
Аннотация: объектом изучения в данной работе является ботуобинский продуктивный горизонт Среднеботуобинского нефтегазоконденсатного месторождения, расположенного в центральной части Мирнинского выступа Непско-Ботуобинской антеклизы. В последние годы в ходе активного бурения на месторождении продуктивный горизонт охарактеризован новым керновым материалом высокого качества, что позволило провести детальное седиментологическое исследование. $B$ результате этих работ была получена новая информаџия об обстановках осадконакопления. Изучаемый объект представляет собой песчаный комплекс дельтового генезиса. Его формирование происходило в этап высокого стояния уровня моря в результате проградации дельть 6 относительно глубоководный морской бассейн. Снос материала происходил с северо-запада на юговосток. Вынос материала в бассейн осуществляли две флювиальные системы, формирующие отдельные дельты. Выявлено, что в зависимости от преобладающих течений происходила трансформация дельтовых конусов выноса. Наилучшими фильтраџионно-емкостными свойствами обладают песчаники береговых валов, верхнего фронта дельты и распределительных каналов. Основным контролирующим фактором, влияющим на фильтрационно-емкостные свойства пород пласта, является процентное содержание и тип цемента. Впервые в данной работе приведена детальная характеристика основных фацииальных зон, дана минералогическая и фильтрационно-емкостная характеристика пород пласта, а также представлена концептуальная фациальная схема.

Ключевые слова: Восточная Сибирь, Непско-Ботуобинская антеклиза, венд, Среднеботуобинское месторождение, Ботуобинский продуктивный горизонт, фациальный анализ, дельтовые отложения
\end{abstract}

\section{CONCEPTUAL MODEL SEDIMENTOLOGICAL BOTUOBA PRODUCTIVE HORIZONS OF SREDNEBOTUOBINSKOYE OIL AND GAS CONDENSATE DEPOSIT}

Abstract: the object of study in this work is the Botuobin productive horizon of the srednebotuobinskoye oil and gas condensate field located in the Central part of the Mirninsky ledge of the NepskoBotuobinskoye antekliza. In recent years, during active drilling at the field productive horizon is characterized by a new core material of high quality, which allowed to conduct a detailed sedimentological study. As a result of this work, new information was obtained on the conditions of sedimentation. The object under study is a sandy complex of Delta Genesis. Its formation took place at the stage of high sea level as a result of the Delta's fencing into a relatively deep sea basin. The demolition of the material took place from North-West to South-East. The removal of material into the pool was carried out by two fluvial systems forming separate deltas. It is revealed that depending on the prevailing currents there was a transformation of the Delta cones of removal. Sandstones of coastal shafts, the upper front of the Delta and distribution channels have the best filtration and capacitive properties. The main controlling factor affecting the filtration and reservoir properties of reservoir rocks is the percentage and type of cement. For the first time in this work the detailed characteristic of the main facies zones is given, the mineralogical and filtration-capacitive characteristic of reservoir rocks is given, and also the conceptual facies scheme is presented.

Key words: Eastern Siberia, Nepsko-Botuobinskoe antekliza, vend, Srednebotuobinsky deposit, Botuobinsk productive horizon, facies analysis, delta deposits 


\section{Введение}

Промышленные залежи нефти и газа в пределах Непско-Ботуобинской антеклизы установлены в широком стратиграфическом диапазоне от подсолевого карбонатного комплекса венд-нижнего кембрия (осинский горизонт - пласты Б1 и Б2, юряхский пласты Б3-Б5) до терригенной базальной толщи венда (непский, ботуобинский, харыстанский, улаханский, хамакинский, талахский, вилючанский горизонты).


Рuc. 1. Расположение района исследования. $A$ - Расположение Мирнинского выступа Непско-Ботуобинской антеклизы; $B$ - Расположение изученных скважин на Среднеботуобинском месторождении: 1 - границы Лено-Тунгуской нефтегазоносной области; 2 - границы Непско-Ботуобинской антеклизы; 3 - границы Непского свода; 4 - границы Мирнинского выступа; 5 - Среднеботуобинское месторождение; 6 - скважина и ее номер.

Ботуобинский продуктивный горизонт (далее по тексту Бт) широко распространён на территории якутской части Непско-Ботуобинской антеклизы. Согласно действующей стратиграфической схемы ботуобинский продуктивный горизонт приурочен к нижней подсвите бюкской свиты тирского горизонта верхнего отдела венда и представлен песчаниками с подчиненными прослоями алевролитов и аргиллитов. Общая мощность горизонта варьирует от 10 до 40 м, в среднем составляет около 20 м. Максимальные мощности до 40 м отмечены на Бес-Юряхской площади. На Мирнинском выступе к пласту Бт приурочены основные залежи таких крупных месторождений как Среднеботуобинское, Тас-Юряхское, а также около десятка средних и мелких по запасам месторождений $[1,2]$ (рис. 1).

Представления о фациальном строении ботуобинского горизонта, как о любом объекте, в значительной степени определяются масштабом решаемых задач. При переходе от регионального этапа ГРР к поисковому и разведочному этапам и далее к эксплуатации месторождения, все исследователи сталкиваются с необходимостью актуализации геологической модели на основе новых данных бурения.

Целью работы является построение концептуальной фациальной модели Среднеботуобинского месторождения, на основе детального литолого-фациального анализа керна с привлечением сейсмических данных и ГИС.

При детальном седиментологическом описании керна ряда скважин в 2015 г. экспертом по литологии и седиментологии ООО ТННЦ Вилесовым А. П. были выделены признаки, указывающие на более сложное строение разреза и на принципиально другие фациальные условия формирования пласта Бт. В частности, была предложена модель проградирующей волновой дельты с линзовидным строением песчаных тел.

\section{Материалы и методы}

На первом этапе производился литолого-седиментологический анализ отложений ботуобинского горизонта с построением седиментологических колонок. Всего изучено семь скважин, с суммарным выносом керна в интервале нижнебюкской подсвиты 220 м. По диагностическим признакам фаций (структура, текстура, наличие ихнофоссилий, органические остатки, контакты и переходы) установлено, что отложения пласта Бт формировались в дельтовой обстановке. При работе с керновым материалом и интерпретации результатов седиментологического анализа использовались труды известных исследователей в области фациального анализа: Чернова О. С. [3]; Лидер М. Р. [4]; Рейнек Г.-Э., Сингх И. Б. [5] и др. [6-9].

На дельтовый генезис отложений указывают следующие признаки:

1. Развитие в нижней части разреза преимущественно глинистых отложений продельты, а в верхней песчаных осадков склона фронта дельты, устьевых баров, распределительных каналов и береговых валов;

2. Проградационное строение комплекса с увеличение зернистости вверх по разрезу;

3. Преобладание текстур разнообразной косой слоистости в песчаниках;

4. Наличие многочисленных текстур оползания (конволютная слоистость) в интервале перехода от 
глинистых к песчаным отложениям;

5. Дистальные турбидиты;

6. Расположение песчаного комплекса пласта Бт Среднеботуобинского месторождения в соответствующих палеогеоморфологических условиях;

Следующим этапом работы стало построение концептуальной фациальной модели. Проведен комплексный анализ данных седиментологического изучения керна, карт мощностей, ГИС, карт сейсмических атрибутов, выполнен ряд фациальных корреляционных построений по изученным скважинам.

\section{Результаты}

Литологические особенности пород пласта Бт

Породы-коллекторы пласта Бт представлены песчаниками полевошпат-кварцевыми, реже кремнекластито-кварцевыми и мономиктово-кварцевыми (по В. Д. Шутову), от мелко- до крупнозернистых, со слабо развитым межзерновым цементом, и контактовым типом сочленения зерен. Локальное (неравномерное) распространение имеют цементы: карбонатный (преимущественно доломитового состава, до 20\%), сульфатный (до 14\%), глинистый (до 8\%), кварцевый регенерационный (до 4\%), галитовый (до 4\%). Акцессорный комплекс минералов представлен: цирконом, турмалином, ильменитом, магнетитом, апатитом, сфеном, монацитом, эпидотом, антраксолитом и лейкоксеном. Аутигенные минералы, помимо минералов цемента, представлены пиритом. Глинистая составляющая пород представлена в основном гидрослюдой (до $100 \%$ от массы навески), глинами группы смектитов (до 27\%), хлоритом (до 19\%), каолинитом (до 7\%), монтмориллонитом $(0,1 \%)$. Единичными участками отмечается черное и тёмно-бурое битуминозное вещество в виде плёнок и примазок по контурам обломков на стенках и в устьях полых пор (до 2-3\%). Из постседиментационных изменений отмечаются: регенерация кварца, полевых шпатов и частичное растворение последних. Отличительной особенностью исследуемого пласта является постепенный переход от пелито-алевритовых (в подошве) к псефито-песчаным (в кровле) структурам. Карбонатный и глинистый материал прослеживается по всему разрезу с разницей в его содержании от долей до 15$20 \%$, при этом галитовый и сульфатный цемент характерен преимущественно для песчаных отложений, залегающих в кровле пласта.

\section{Характеристика фаций пласта Бт}

В результате седиментологического анализа керна выделены следующие фации: продельта; нижняя часть склона фронта дельты; верхняя часть склона фронта дельты, включая устьевые бары; распределительные каналы; береговые валы. Отложения фронта дельты имеют преимущественно песчаный состав и залегают на глинистых осадках продельты. Фронт дельты представлен разрезами с увеличением зернистости песчаников вверх. В береговой зоне дельты волнового типа подавляющее количество осадков устьевых баров перерабатывается волновыми процессами и переоткладывается вдоль береговой зоны в виде вытянутых пляжевых гребней (береговых валов). На отложения фронта дельты и пляжевых гребней приходится наибольшая масса песчаных осадков дельты волнового типа. Отложения распределительных каналов залегают среди песчаных наносов пляжевых гребней и ориентированы в крест простирания береговой линии. Далее приводится детальная характеристика выделенных фаций снизу вверх по разрезу (рис. 2, 3, 4).

Фация продельты. Фация сложена микро-тонкослоистыми аргиллитами и глинистыми алевролитами с плитчатой отдельностью. Микрослоистые аргиллиты и мелкозернистые глинистые алевролиты преобладают в нижней и средней части продельтового склона и постепенно переходят в тонкослоистые разнозернистые алевролиты верхней части продельтового склона. Породы плотные. Встречаются единичные отпечатки мягкотелых организмов (медузоиды), следы биотурбации и органический шлам. В основании элементарных циклитов залегают аргиллиты, в кровле - алевролиты. Значение пористости в среднем составляет $3,4 \%$, проницаемости 0,2 мД. Основными диагностическими признаками по ГИС являются высокие значения GK, ННКт и низкие значения ВК.

Интерпретация: формирование осадков продельтового склона происходило в дистальной части дельтового склона при поступлении алевритового и глинистого материала в виде взвеси, на глубинах ниже волнового базиса.

Фация нижней части склона фронта дельты. Фация представлена полосчатыми разнозернистыми алевролитами, мелкозернистыми алевро-песчаниками и разнозернистыми, преимущественно мелкозернистыми песчаниками. Строение разреза фации в разных скважинах отличается крайней неоднородностью. Это связано, обычно, с небольшой толщиной прослоев тех или иных пород и неравномерностью их переслаивания. В алевролитах и алевро-песчаниках присутствует конволютная слоистость, свидетельствующая о подводно-оползневых процессах. Песчаники с тонкой, слабоволнистой и косой слоистостью (толщиной до $0,25 \mathrm{~cm}$ ), пористые и слабо нефтенасыщенные. Алевролиты и алевропесчаники плотные. В основании элементарного циклита лежат алевролиты, в кровле - песчаники. Мощность песчаных отложений увеличивается в юго-западном направлении. Значение пористости в среднем составляет 7,1\%, проницаемости 22 мД. Основными диагностическими признаками по ГИС являются неравномерно высокие значения $\mathrm{GK}$, ННКт и низкие значения ВК.

Интерпретация: формирование осадков соответствует нижней части дельтового склона. В этих условиях довольно обычны процессы оползания нелитифицированных осадков, которые быстро накапливаются в верхней части склона и гравитационно нестабильны. 

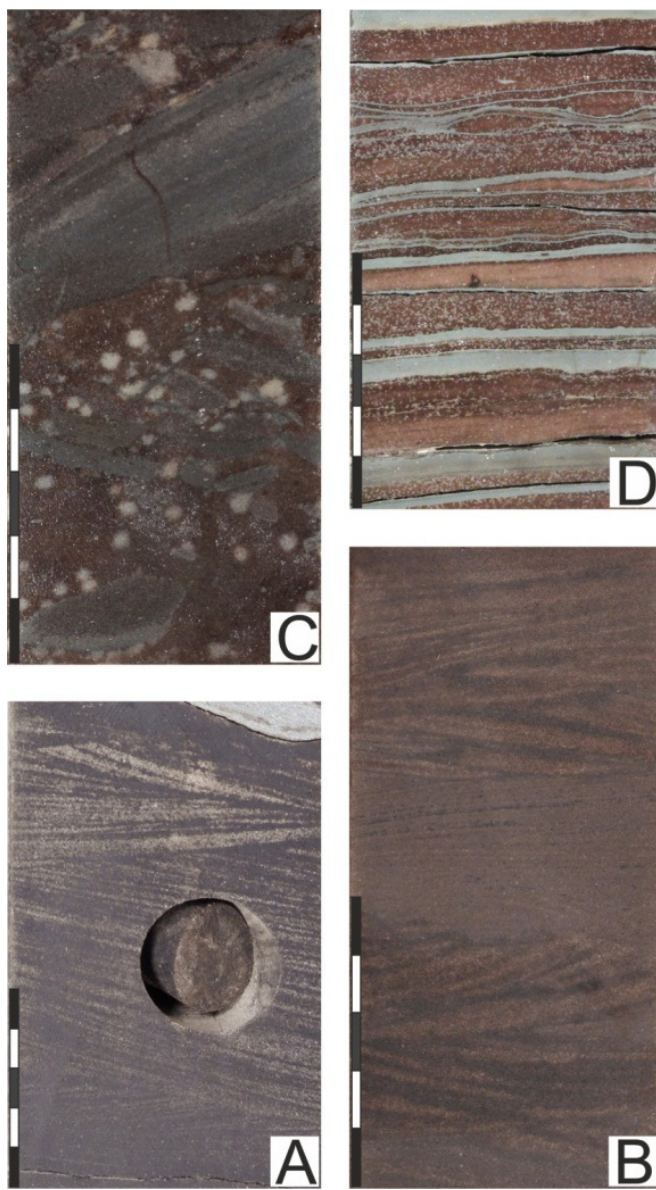

A


Puc. 2. Фото таблица характерных текстур пород нижнебюкской подсвиты: $A$ - песчаники битумо-нефтенасыщенные, средне-мелкозернистые, с косой разнонаправленной слоистостью. Фация береговых валов; $B-$ песчаники нефтенасыщенные, средне-мелкозернистые, с мелкой косой полого наклонной слоистостью. Фация верхней части склона фронта дельты; $C$ песчаники средне-крупнозернистые, с пятнистым сульфатно-карбонатным цементом, с крупной косой слоистостью, c угловато-окатанными интракластами алевролита. Фация распределительного канала; $D$ - тонкое, неравномерное переслаивание алевролитов и песчаников, с мелким пятнистым карбонатным цементом. Фация нижней части склона фронта дельты; $E$ - алевро-песчаники разнозернистые, с конволютной слоистостью. Фация продельты. Длина масштабной линейки 5 см.

Фация верхней части склона фронта дельты. Отложения фации представлены песчаниками мелкои среднезернистыми, с мелкой косой пологонаклонной и волнистой слоистостью, с редкими прослоями алевролитов. Породы пористые, неравномерно нефтенасыщенные. В подошве элементарного циклита лежат мелкозернистые песчаники, в кровле - до перехода в алевролиты. Мощность песчаников увеличивается в северо-восточном направлении. Значение пористости в среднем составляет $15,5 \%$, проницаемости 715 мД. Основными диагностическими признаками по ГИС являются средние значения GK, ВК и низкие значения ННКт.

Интерпретащия: формирование осадков происходило в условиях гравитационной нестабильности при неравномерном поступлении песчаного, алевритового и глинистого материала, при направленном движении флювиальных течений.

Фациия устьевого бара. Отложения фации представлены разнозернистыми песчаниками, преимущественно косослоистыми, реже пологокосослоистыми. Среди них отмечаются внутренние поверхности размыва и конволютная слоистость. В составе фации преобладают крупнокосослойчатые песчаники с наклонными глинистыми слойками. Мощность крупнокосослойчатых серий и гранулометрический состав песчаников имеют тенденцию постепенно уменьшатся к кровле. Значение пористости в среднем составляет $10 \%$, проницаемости 27,5 мД. Основными диагностическими признаками по ГИС являются низкие значения GK и ННКт и средние значения ВК.

Интерпретация: фация устьевых баров фронта дельты формируется в верхней части дельтового склона. Песчаный материал неравномерно поступает по распределительным каналам и разгружается в верхней части дельтового склона - сначала более крупные фракции, затем более мелкие. Фации устьевых баров парагенетически связаны с фациями нижней части склона фронта дельты и распределительных каналов.

Фация распределительного канала. Отложения фации представлены разнозернистыми песчаниками, с крупной косой однонаправленной и разнонаправленной слоистостью, пористыми, нефтенасыщенными. Разнонаправленная слоистость и сдвоенные глинистые слойки свидетельствует о приливном влиянии. В основании элементарного циклита лежат грубо-рупнозернистые песчаники, в кровле - мелкозернистые песчаники. Иногда в подошве распределительного канала наблюдается мелкий гравийный материал и плохоокатанные интракласты алевролита. Значение пористости в среднем составляет 14\%, проницаемости 493 мД. Основными диагностическими признаками по ГИС являются низкие значения $\mathrm{GK}$, ННКт и высокие значения ВК.

Фация устьевого бара. Отложения фации представлены разнозернистыми песчаниками, преимущественно косослоистыми, реже пологокосослоистыми. Среди них отмечаются внутренние поверхности размыва и конволютная слоистость. В составе фации преобладают крупнокосослойчатые песчаники c наклонными глинистыми слойками. Мощность крупнокосослойчатых серий и гранулометрический состав песчаников имеют тенденцию постепенно уменьшатся к кровле. Значение пористости в среднем составляет $10 \%$, проницаемости 27,5 мД. Основными диагностическими признаками по ГИС 


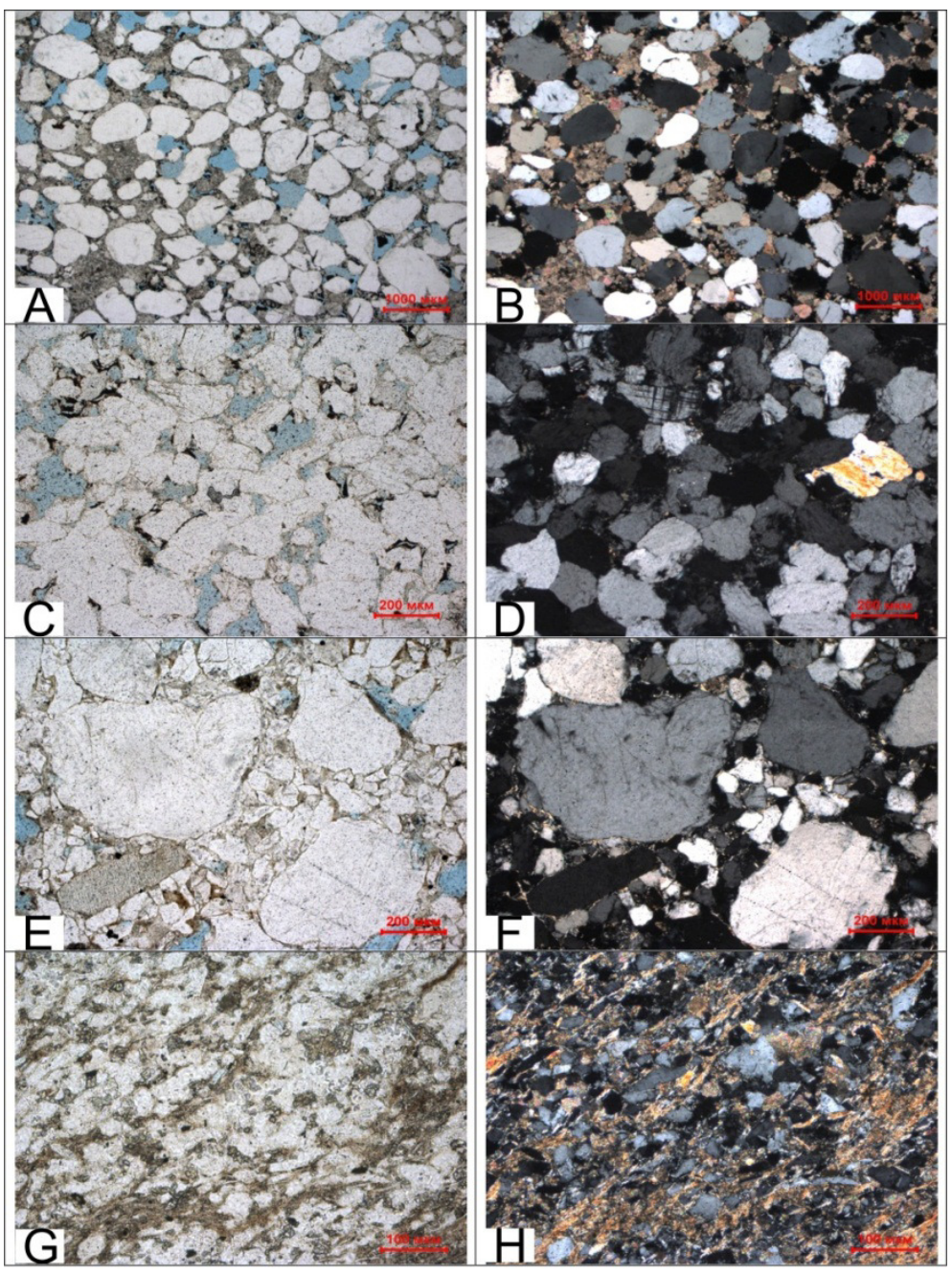

Puc. 3. Фото шлифов основных фациальных зон нижнебюкской подсвиты: А, В - песчаник средне-крупнозернистый, олигомиктовый кварцевый, с плёночно-поровым карбонатным цементом. Вид $A$ - без анализатора, увеличение 20x, B - с анализатором, увеличение 20x; C, D - Песчаник среднемелкозернистый, олигомиктовый кварцевый, преимущественно с бесцементным контактным и регенерационным кварцевым соединением зёрен, со скудным плёночным глинистым цементом и ангидритом в единичных порах. Вид $C$ - без анализатора, увеличение $100 x, D-$ с анализатором, увеличение $100 \mathrm{x}$; E, F - Песчаник тонко-мелкозернистый алевритовый, с беспорядочными включениями обломков крупно- и среднепсаммитовой размерности, олигомиктовый кварцевый, с регенерационным кварцевым, плёнок-поровым серицит-глинистым цементом и карбонатом в единичных порах. Вид $E$ - без анализатора, увеличение $100 \mathrm{x}, F-$ с анализатором, увеличение 100x; G,H - Алевролит крупно-мелкозернистый, слабо песчанистый, олигомиктовый кварцевый, глинистый сидеритизированный. Вид $G$ - без анализатора, увеличение 200, $H$ - с анализатором, увеличение 200.
Фациия берегового вала волновой deльты. Береговые валы выделены в верхней части всех изучаемых скважин. Отложения фации представлены песчаниками от мелко- до крупнозернистых, с массивной текстурой, реже с пологой, субгоризонтальной и мелкой косой слойчатостью, равномерно пористыми, нефтенасыщенными. В основании элементарного циклита лежат крупносреднезернистые, иногда крупнозернистые, в кровле - мелкозернистые песчаники. Значение пористости в среднем составляет $16,3 \%$, проницаемости 614 мД. Основными диагностическими признаками по ГИС являются низкие значения GK, ННКт и ВК.

Интерпретация: формирования осадков происходила вдоль береговой линии с активной волновой гидродинамикой и интенсивным поступлением песчаного материала.

C перерывом на песчаниках лежат строматолитовые разно-кристаллические доломиты с терригенно-карбонатным межскелетным заполнением, образовавшиеся в нормально-морских условиях, выше которых лежат доломиты и сульфатизированные доломиты.

При анализе фильтрационно-емкостных свойств выявлено, что наилучшими коллекторами пласта Бт являются песчаники береговых валов, песчаники верхней части склона фронта дельты и песчаники распределительных каналов. Одним из основных факторов, влияющих на ФЕС, является цемент - его количество и минеральный состав. Негативное влияние на ФЕС оказывают следующие типы цементации: агрегатный и пойкилитовый сульфатно-карбонатный и пойкилитовый, поровый, базальный карбонатно-сульфатный и галитовый Наилучшими свойствами обладают песчаники с регенерационным кварцевым и полевошпат-кварцевым, а также с пленочно-поровым глинистым типом цементов.

\section{Концептуальная седиментологическая схема формирования пласта Бт}

Изучаемый объект представляет собой глинистоалевритово-песчаный комплекс дельтового генезиса, со сложной историей развития, сформировавшийся в два этапа. 


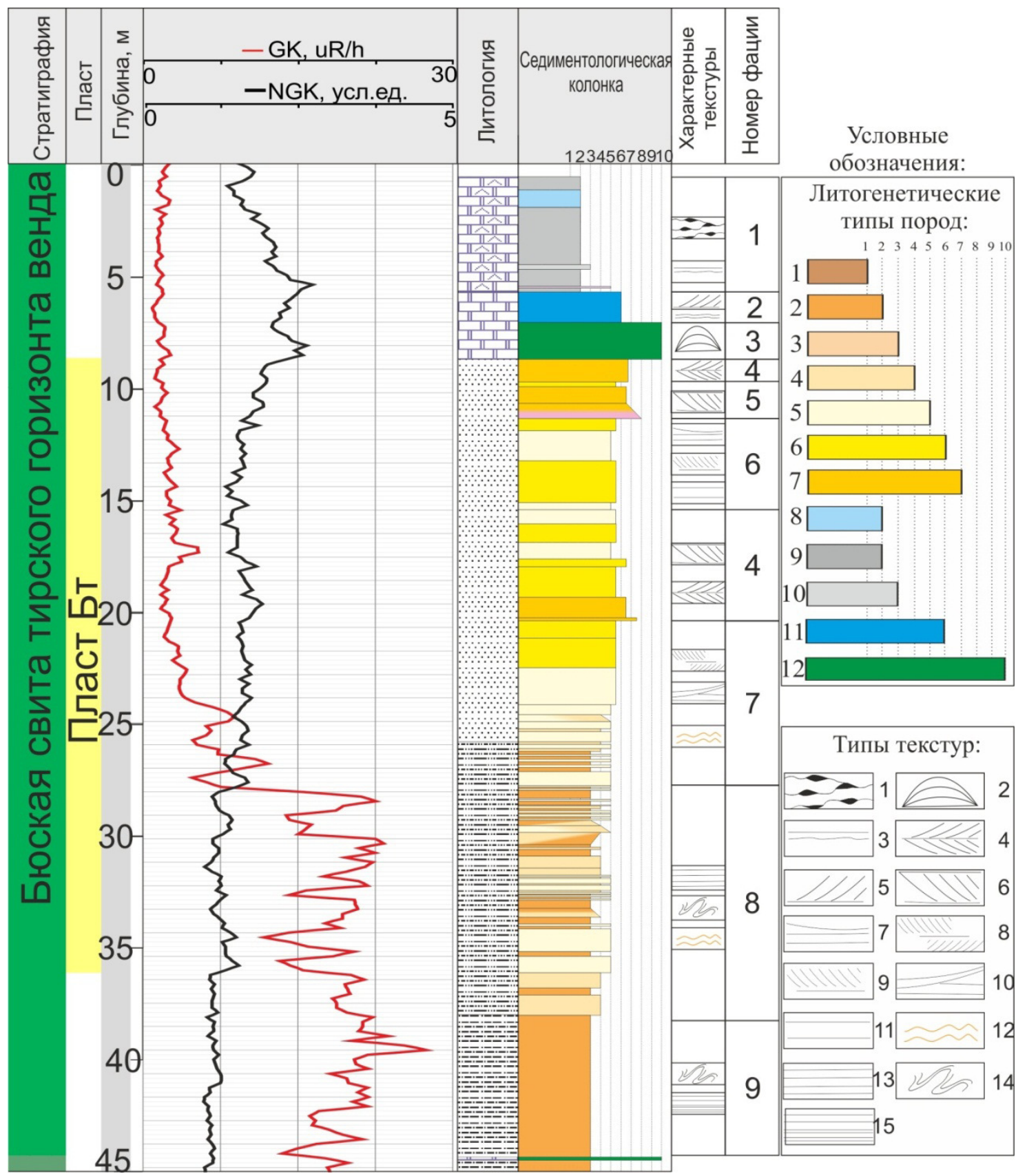

Puc. 4. Схематический пример седиментологического планшета в интервале разреза пласта Бт. Номер фации: 1 - шельфовая лагуна; 2 - карбонатная отмель; 3 - органогенная постройка на литорали; 4 - флювиальный канал с приливным влиянием; 5 флювиальный канал; 6 - береговой вал; 7 - верхний фронт дельты; 8 - нижний фронт дельты; 9 - продельта.

Литогенетические типы пород: 1 - аргиллиты; 2 - алевролиты разнозернистые, глинистые; 3 - алевролиты крупнозернистые; 4 - алевро-песчаники, песчаники алевритовые; 5 - песчаники мелкозернистые; 6 - песчаники среднезернистые; 7 - песчаники крупнозернистые; 8 - ангидрит; 9 - доломиты тонко-микрокристаллические (доломадстоун/мадстоун); 10 - доломиты микрокристаллические с зернами (вакстоун); 11 - доломиты крупнозернистые с микрокристаллическим цементом (рудстоун); 12 - доломиты с каркасными структурообразующими формами (баундстоун в широком смысле).

Tuпы текстур: 1 - желваково-слоистые; 2 - органогенно-слоистые; 3 - тонко и волнисто-слоистые; 4 - крупная косая разнонаправленная слоистость; 5 - косая слоистость; 6 - крупная косая однонаправленная слоистость; 7 - пологая и пологая косая слоистость; 8 - мелкая косая разнонаправленная слоистость; 9 - мелкая косая однонаправленная слоистость; 10 - пологая косая и срезанная слоистость; 11 - масивная; 12 - волнистая слоистость подчеркнутая тонкими прожилками глинистого материала; 13 - тонкослоистые; 14 - конволютная слоистость; 15 - микро и тонкослоистые.

На первом конструктивном этапе, в раннебюкское время, вынос материала в бассейн осуществляли две флювиальные системы, формирующие отдельные дельты, что подтверждается бимодальностью распределения грансостава песчаников береговых валов (рис.5).

В нижней части разреза всех изученных скважин мы наблюдаем глинистые отложения продельты, 
которые выше по разрезу переходят в отложения нижней части склона фронта дельты, представленные переслаиванием песчаников и алевролитов. Вышележащие отложения верхней части склона фронта дельты представлены разнозернистыми песчаниками, с различной степенью сортировки. По фациальному профилю отмечается увеличение мощности отложений продельты и нижней части склона фронта дельты в юго-западном направлении. Данное увеличение мощности, может быть, связано с преобладаем юго-западных течений в это время (рис. 6).

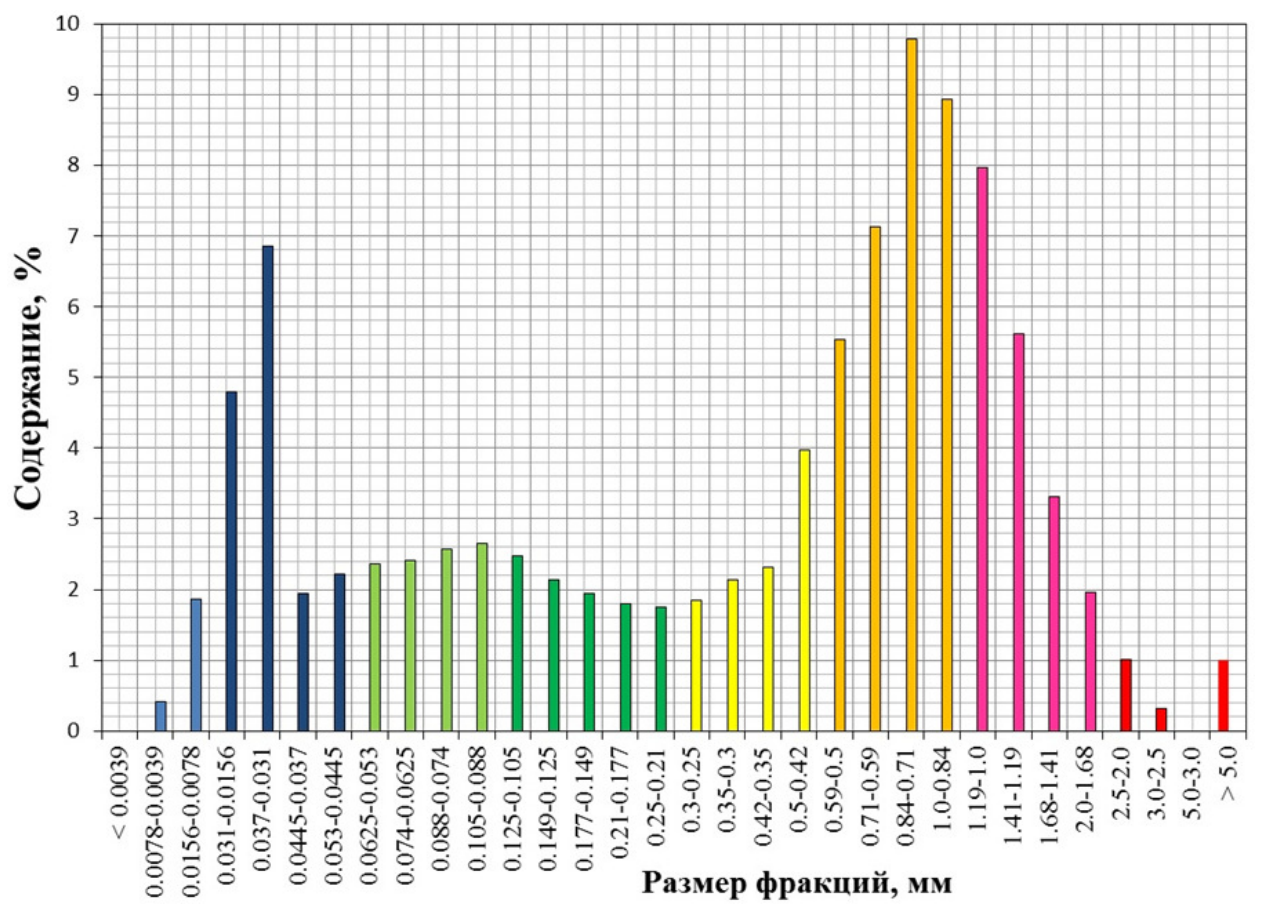

Puc. 5. Песчаник мелко-средне-грубо-крупнозернистый, алевритистый. По гистограмме видно бимодальное распределение гранулометрических фракций.

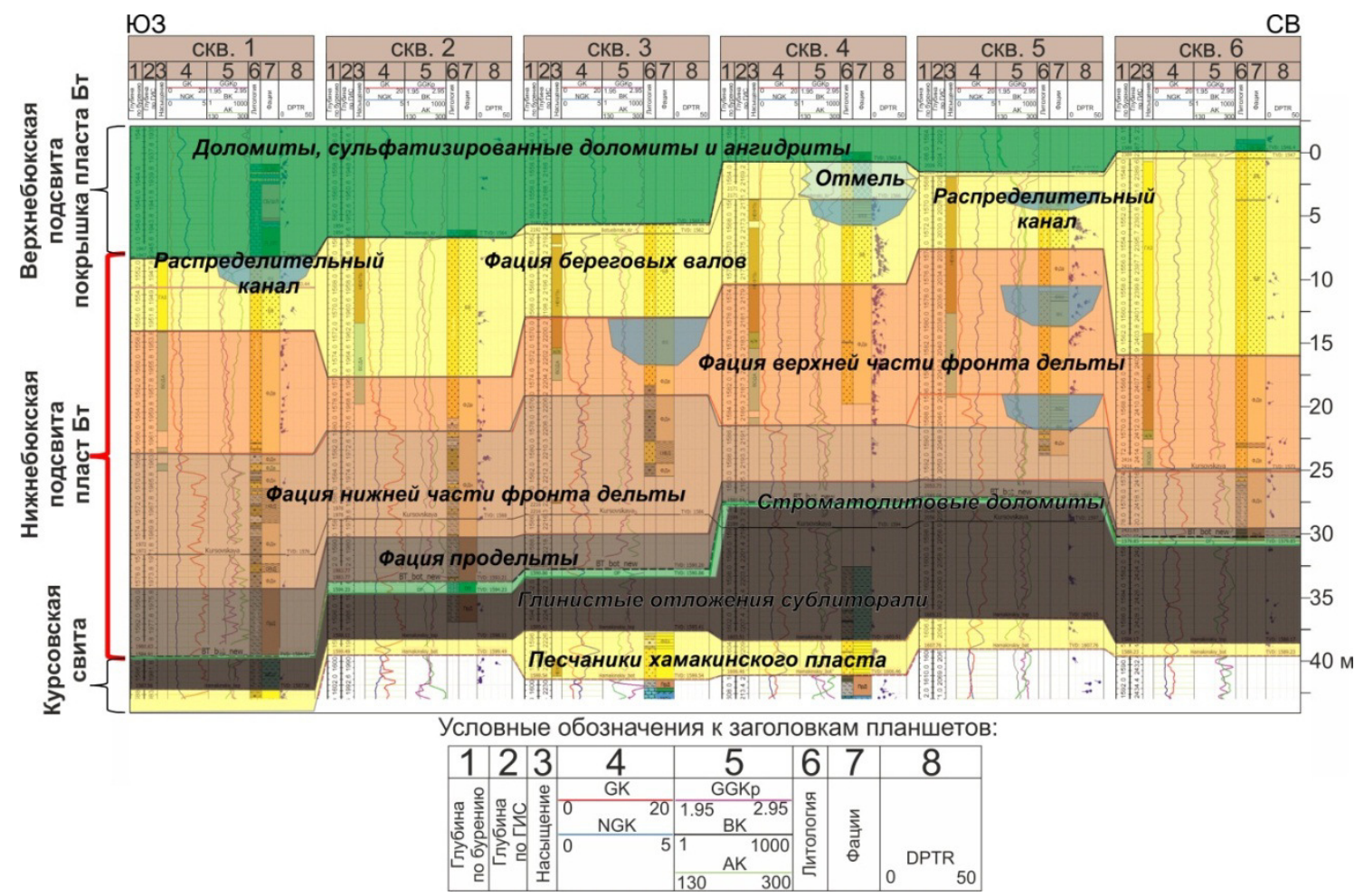

Puc. 6. Фациальный профиль по линии скважин 1-6. 




Puc. 7. Объемная концептуальная модель строения волновой дельты (по Allen 1989, с дополнениями автора) [9].



Распред. Устьевые Нижний фронт ПродельтаШельф каналы бары дельты

Puc. 8. Принципиальная фациальная модель позднебюкского времени територии Среднеботуобинского месторождения. Рамкой обведена граница лицензионного участка.

Во второй части раннебюкского времени, на деструктивном этапе, начинают преобладать волновые процессы, дельта трансформируется в волновую (рис. 7). Формируются береговые валы, состоящие из хорошо окатанных и отсортированных песков. Распределительные каналы разрезают береговые валы, вынося терригенный материал в зону верхнего склона фронта дельты, формируя устьевые бары.
В позднебюкское время происходит смена условий осадконакопления на мелководную литораль с бентосными микробиальными сообществами, формирующими строматолиты.

Седиментологические исследования доказывают, что образование пласта Бт было связано с проградацией дельты в относительно глубоководный морской бассейн (рис. 8).

\section{Заключение}

Седиментологический анализ керна поисковоэксплуатационных скважин Среднеботуобинского месторождения позволил получить следующие результаты:

1. В раннебюкское время происходило формирование ботуобинского продуктивного горизонта в условиях флювиальной (речной) дельты с последующей трансформацией ее в волновую;

2. Формирование ботуобинского продуктивного горизонта происходило в результате проградации дельты в относительно глубоководный морской бассейн;

3. В раннебюкское время вынос материала в бассейн осуществляли две флювиальные системы, формирующие отдельные дельты, что подтверждается бимодальностью распределения грансостава и дешифрированием сейсмических слайсов;

4. В это время господствовали вдольбереговые течения, что выразилось в увеличении мощности отложений нижнего фронта дельты и продельты в юговосточном направлении; 
5. Во второй части раннебюкского времени начинают преобладать волновые процессы, что вместе с постепенным снижением объемов поступающего материала в бассейн привело к образованию волновой дельты. Наблюдается увеличение мощности отложений береговых валов в северо-восточном направлении;

6. Наилучшими ФЕС обладают песчаники береговых валов, верхнего фронта дельты и распределительных каналов. Основным контролирующим фактором, влияющим на фильтрационно-емкостные свойства пород пласта Бт, является содержание и тип цемента;

6. Построена концептуальная фациальная схема образования пласта Бт. Снос материала происходил с северо-запада на юго-восток, в этом направлении в сторону бассейна уменьшается мощность песчаных отложений береговых валов и верхней части склона фронта дельты, и напротив, увеличение глинистотерригенных и глинистых осадков нижней части склона фронта дельты и продельты.

Таким образом, в работе впервые рассмотрена дельтовая модель формирования пласта Бт. Произведено расчленение разреза на фации и определены критерии их выделения по ГИС. Построена концептуальная фациальная модель месторождения.

В заключение автор выражает благодарность кандидату геолого-минералогических наук, эксперту по литологии и седиментологии ООО «ТННЦ» Вилесову А. П. за проявленный интерес к работе, плодотворные дискуссии и иенные советы.

ООО «Тюменский нефтяной научный иеентр», г. Тюмень

Плюснин Алексей Владимирович, ведущий специалист E-mail:avplyusnin@tnnc.rosneft.ru

Тел.: +7 (3452) 550055

\section{ЛИТЕРАТУРА}

1. Фомин, А. М. Особенности строения и условия формирования ботуобинского горизонта в пределах Мирнинского выступа / А. М. Фомин, С. А. Моисеев, Н. Ч. Павлов // Геология, геофизика и разработка нефтяных и газовых месторождений. - 2017. - Т. 8. - С. 4-11.

2. Шемин, Г. Г. Геология и перспективы нефтегазоносности венда и нижнего кембрия центральных районов Сибирской платформы (Непско-Ботуобинская, Байкитская антеклизы и Катангская седловина) / Г. Г. Шемин. - Новосибирск : СО РАН, 2007. - 467 с.

3. Чернова, О. С. Литолого-фациальный и формационный анализ нефтегазоносных толщ: Учебное пособие по короткому курсу / О. С. Чернова. - Томск : ЦППС НД, 2008. $250 \mathrm{c}$.

4. Лидер, М. Р. Седиментология / М. Р. Лидер. - Процессы и продукты. М. : Мир, 1986. -439 с.

5. Рейнек, Г.-Э. Обстановки терригенного осадконакопления (с рассмотрением кластических осадков) / Г.-Э. Рейнек, И. Б. Сингх. - М. : Недра, 1981. - 439 с.

6. Predicting Shallow Marine Reservoir Heterogeneity Using a High Resolution Mapping Approach, Brigadier Formation, NWS, Australia / R. B. Ainsworth [et al.] // SPE Asia Pacific Oil \& Gas Conference and Exhibition. - 2010. - P. 1-13.

7. Allen, P. A. Lakes. In H. G. Reading (ed.), Sedimentary environments and facies./ P. A. Allen, J. D. Collinson // Blackwell Scientific Publications, Oxford. - 1986. - P. 63-94.

8. Einsele, G. Sedimentary basins: Evolution, facies, and sediment budget. / G. Einsele. - Berlin: Springer-Verlag. - 2000. $792 \mathrm{p}$.

9. Facies Models 4 / Ed. Noel P. Jemes, Robert W. Dalrymple. - GEOtext 6. Geological Association of Canada. - 2010. $587 \mathrm{p}$.

«Tyumen Oil Research Center» (TNNC), Tyumen

Plyusnin A. V., leading specialist E-mail:avplyusnin@tnnc.rosneft.ru Tel.: +7 (3452) 550055 